\title{
ab initio X-ray structure determination of $\mathrm{NaAl}(\mathrm{SO} 4) 2$ \\ M. Boujelben and T. Mhiri \\ Laboratory of the Physico-Chemistry of Solid States. LR11 ES51. of Sfax. Road \\ of Soukra km 4. Sfax3071. Tunisia.
}

\begin{abstract}
The sodium aluminium disulphate $\mathrm{NaAl}\left(\mathrm{SO}_{4}\right)_{2}$ has been obtained after calcinations at $300{ }^{\circ} \mathrm{C}$ of $\mathrm{NaAl}\left(\mathrm{SO}_{4}\right)_{2} .12 \mathrm{H}_{2} \mathrm{O}$ alum. The structure of this compound has been refined from powder $\mathrm{X}$-ray diffraction data using the Rietveld method. This compound crystallises in trigonal system P 321 with the following parameters: $a=4.749(12) \AA, c=8.314(4) \AA(Z=$ 1). The final refinement led to $R_{F}=6.3 \%, R_{B}=4.12 \%$. In the proposed model the sulfate ions is in disorder between two nonequivalent crystallographic sites with probabilities $p_{1} / p_{2}=0.30 / 70$. The atomic arrangement of $\mathrm{NaAl}\left(\mathrm{SO}_{4}\right)_{2}$ is characterised by two different alternating layers parallel to (001): the first layer is composed of corner-linked $\mathrm{AlO}_{6}$ octhahedra and $\mathrm{SO}_{4}$ tetrahedra, the second layer is built from monovalent $\mathrm{Na}^{+}$.
\end{abstract}

Key words: Alum; Rietveld method; X-ray powder diffraction; Anhydrous Alum ; disordered structure.

\section{Council for Innovative Research}

Peer Review Research Publishing System

Journal: Journal of Advances in Chemistry

Vol. 5, No. 1

editor@cirworld.com

www.cirworld.com, member.cirworld.com 


\section{Introduction}

The extensive $\mathrm{AB}\left(\mathrm{TO}_{4}\right)_{2}$ family where $\mathrm{A}=$ monovalent $\mathrm{Na}, \mathrm{K}, \mathrm{Rb}, \mathrm{Cs}, \mathrm{Ag}, \mathrm{NH}_{4}$ or divalent $\mathrm{Ca}, \mathrm{Sr}, \mathrm{Ba}, \mathrm{B}=$ trivalent $\mathrm{Sc}, \mathrm{V}$, $\mathrm{Cr}, \mathrm{Mn}, \mathrm{Fe}, \mathrm{Al}, \mathrm{Ga}, \mathrm{Rh}$, or tetravalent $\mathrm{Mo}, \mathrm{Ge}, \mathrm{Ti}, \mathrm{Zr}, \mathrm{Hf}, \mathrm{Sn}$, or pentavalent $\mathrm{Ta}$, and $\mathrm{T}=$ hexavalent $\mathrm{S}$, Se, $\mathrm{Cr}$ or pentavalent $P, A s[1-2]$, is intensively investigated. From a structural point of view, $\mathrm{RbFe}\left(\mathrm{SeO}_{4}\right)_{2}$ [ 3] $(\mathrm{P} 321$ symmetry and a0 $=\mathrm{b}_{0}=5.005 \AA$ and $\mathrm{c}_{0}=8.548 \AA$ ) can be considered as a reference in this family of compounds. Several type of supergroup are reported in literature, examples: Yavapaiite $\mathrm{KFe}\left(\mathrm{SO}_{4}\right)_{2}$, and $\mathrm{NaFe}\left(\mathrm{SeO}_{4}\right)_{2}[4]$, and phosphates such as $\mathrm{BaMo}\left(\mathrm{PO}_{4}\right)_{2}[5], \mathrm{Ba}(\mathrm{Hf}, \mathrm{Zr})\left(\mathrm{PO}_{4}\right)_{2}$ [6], all crystallise in the system monoclinic, space group $\mathrm{C} 2 / \mathrm{m}$, the unit cell parameters a $\approx \sqrt{3} \mathrm{a}_{0}, \mathrm{~b} \approx \mathrm{b}_{0}$ and $\mathrm{c} \approx \mathrm{c}_{0}$. Compounds from other supergroup are selenates like $\mathrm{KMn}\left(\mathrm{SeO}_{4}\right)_{2}[4] . \mathrm{CsTa}\left(\mathrm{PO}_{4}\right)_{2}$ [7] Crystallise in the system triclinic, space group $\mathrm{P}-1$ the unit cell parameters $\mathrm{a} \approx \mathrm{a}_{0}, \mathrm{~b} \approx \mathrm{a}_{0}$ and $\mathrm{c} \approx \mathrm{c}_{0}$

The existence of $\mathrm{NaAl}\left(\mathrm{SO}_{4}\right)_{2}$ was first reported by Bernard [8](1966), unit cell parameters and space group have been proposed, but this structure has not determined. In this paper we proposed the X-ray determination of the structure by $\mathrm{X}$ ray powder diffraction.

\section{Experimental}

\section{1- Preparation}

Alum $\mathrm{NaAl}\left(\mathrm{SO}_{4}\right)_{2} \cdot 12 \mathrm{H}_{2} \mathrm{O}$ crystals were prepared by a slow evaporation of aqueous solutions containing stoichiometric amounts of $\mathrm{Na}_{2} \mathrm{SO}_{4}$ and $\mathrm{Al}_{2}\left(\mathrm{SO}_{4}\right)_{3} . \mathrm{XH}_{2} \mathrm{O}$ salts. The sodium aluminium disulphate $\mathrm{NaAl}\left(\mathrm{SO}_{4}\right)_{2}$ has been obtained after calcinations at $300^{\circ} \mathrm{C}$ of $\mathrm{NaAl}\left(\mathrm{SO}_{4}\right)_{2} .12 \mathrm{H}_{2} \mathrm{O}$ alum.

X-ray diffraction: the powder X-ray pattern of this compound was collected by using a Siemens D 5001 diffractometer with a monochromated CoK $\alpha$ radiation. Diffraction intensity was measured between $10^{\circ}$ and $140^{\circ}$, with a $2 \theta$ step of $0.017^{\circ}$ for 17s per point. The data was collected at room temperature. Crystalline structure was refined with the Rietveld technique [9] using Fullprof 2009 code [10]. Peak profiles were modelled with pseudo-Voigt functions [11]. The observed intensities as extracted from the X-ray data by the program Fullprof [12].

\section{Thermal analysis}

The thermo gravimetric (TG) Netzsch and differential thermal analysis (DTA) were performed in air atmosphere with a thermal analyzer. Measurements were taken from 25 to $400^{\circ}$ with a heating rate of $5 \% \mathrm{~min}$.

The experimental curve of the thermo gravimetric analysis (TG) and differential thermal analysis (DSC) measurement of $\mathrm{NaAl}\left(\mathrm{SO}_{4}\right)_{2} \cdot 12 \mathrm{H}_{2} \mathrm{O}$ are reported in fig1. The $12 \mathrm{H}_{2} \mathrm{O}$ per formula were confirmed, and several intermediates were revealed, $\mathrm{NaAl}\left(\mathrm{SO}_{4}\right)_{2} 8 \mathrm{H}_{2} \mathrm{O}, \mathrm{NaAl}\left(\mathrm{SO}_{4}\right)_{2} 4 \mathrm{H}_{2} \mathrm{O}$ and $\mathrm{NaAl}\left(\mathrm{SO}_{4}\right)_{2}$. The anhydrous compound $\mathrm{NaAl}\left(\mathrm{SO}_{4}\right)_{2}$ (that can be obtained at $250^{\circ} \mathrm{C}$ ) is instable at room temperature in ambient air. 


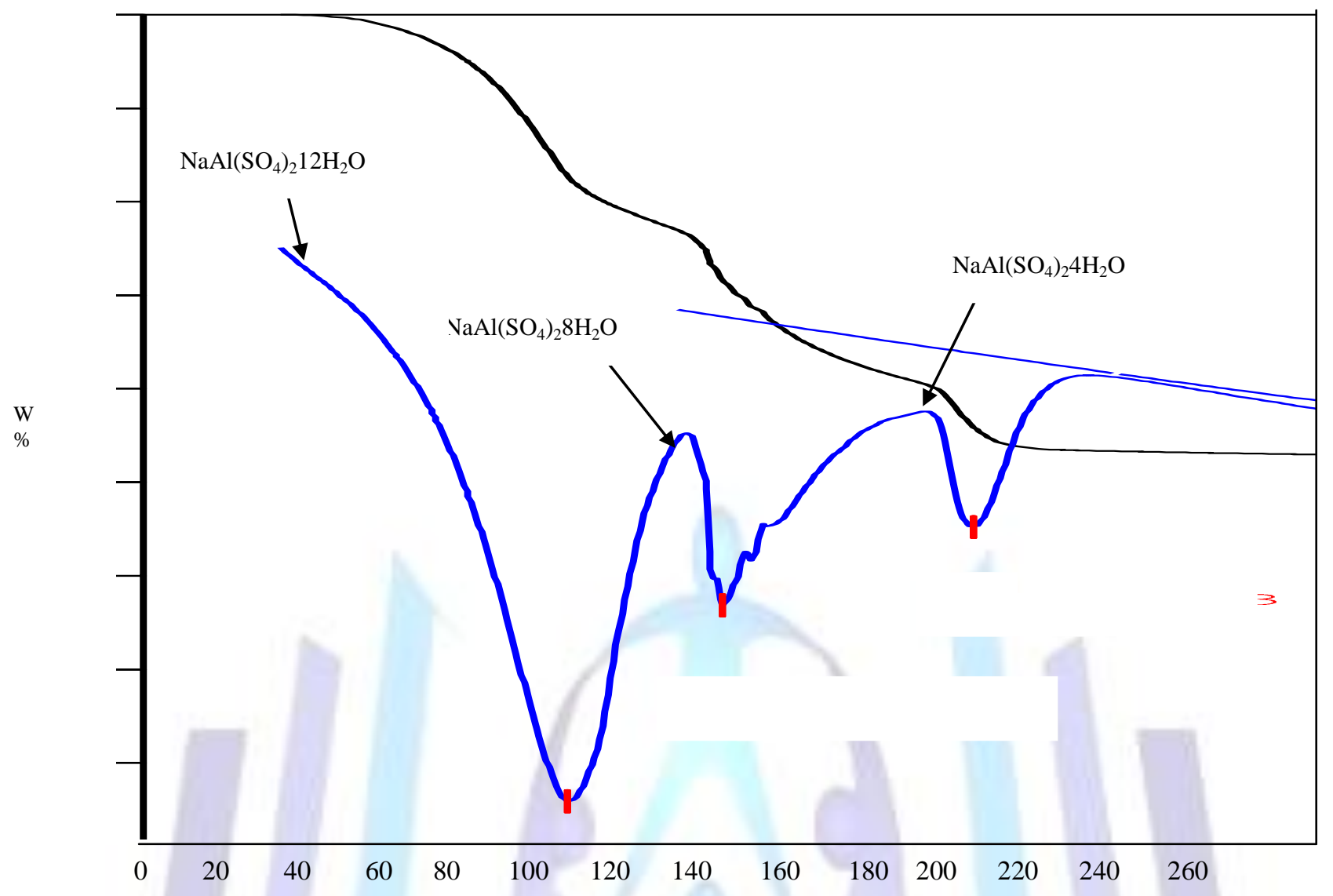

Figure. 1. Differential thermal analysis curves of $\mathrm{NaAl}\left(\mathrm{SO}_{4}\right)_{2} \cdot 12 \mathrm{H}_{2} \mathrm{O}$.

\section{III- ab-initio structure determination of $\mathrm{NaAl}\left(\mathrm{SO}_{4}\right)_{2}$}

\section{A. Structure solution}

The alum $\mathrm{NaAl}\left(\mathrm{SO}_{4}\right)_{2}$ compound is characterized by space group $\mathrm{P} 321$ and has the trigonal, anhydrous alum type structure. The cell constants and atomic parameters of the starting model were taken from the X-ray structure determination of the pure potassium alum $\mathrm{KAl}\left(\mathrm{SO}_{4}\right)_{2}$ [13], space group $\mathrm{P} 321$. After refinement, the structural model indicators converged to $R_{p}=0.15$ and $R_{W P}=0.16$, with a high thermal parameter of the $\mathrm{O} 2$ and a characteristic difference is obtained between observed and calculated intensities of the (300) reflection (fig. 2a). The large $B$ value of O2 led us to suppose that this site is partially occupied. The refinements of occupancy site $4 \mathrm{e}$ of oxygen atoms show $50 \%$ occupation of these sites. A difference Fourier applied to the observed intensities (extracted from the X-ray data by the program FULLPROF (Le Bail method)) using SHELXL-97 [11] was carried out to check a possible oxygen atom positions C3 at approximately $1.6 \AA$ from sulfur at $(0.6,0.95,0.35)$ O3. Suggest the existence of disordered sulfate ions in this structure. After refinement, the occupancies of $\mathrm{O} 2$ and $\mathrm{O} 3$ are respectively $70 \%$ and $30 \%$. The final refinement gave a much better description of the (300) peak shape (fig. 2b). Generally, the effect of the disordered structure was an improvement of the fit to the diffraction peaks (fig. 3) and lowering of Rp and Rwp by 0,189 / 0.188 to 0,14/0,14.

Fig. 3 shows the powder X-Ray diffraction pattern and the difference between the calculated and the observed pattern. The crystallographic parameters and atomic coordinates are presented in table 1 and 2. Final atomic coordinates, isotropic displacement parameters, bond distances and angles are reported in table 3. Projection of the structure is set in Fig 4. 

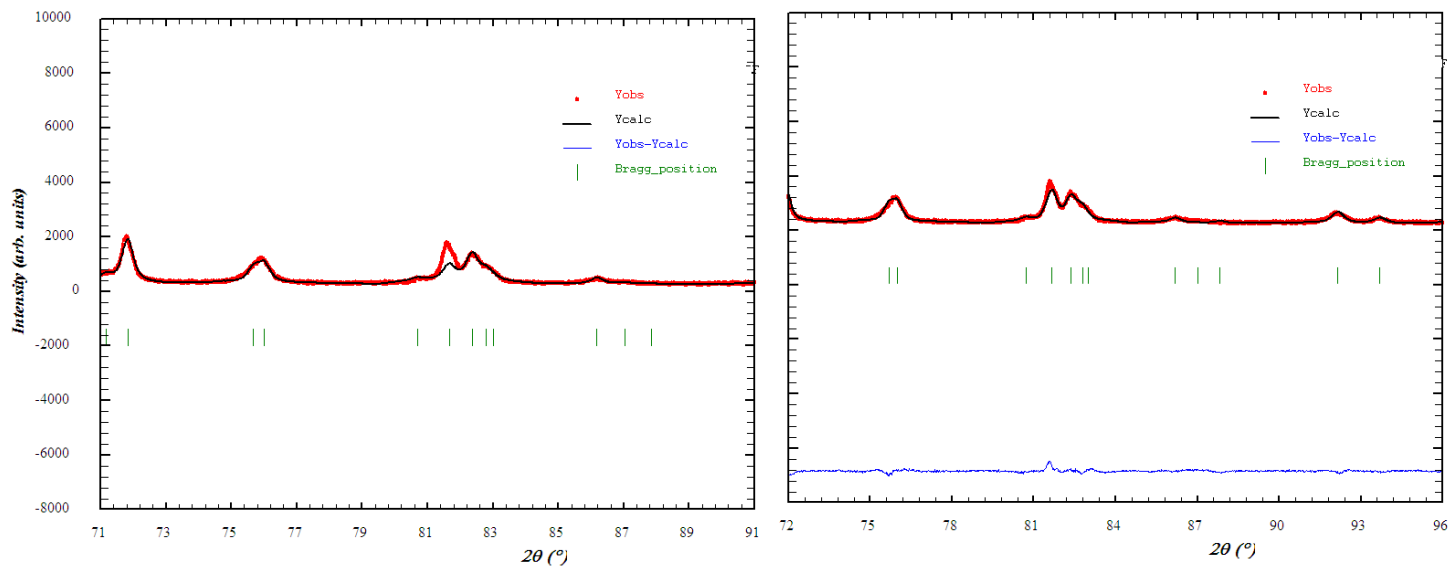

Figure.2. Experimental data and the fit through X-ray powder diffraction spectra around the (300) reflexion taken from Rietveld refinement of the ordinate structure (a) leading to $R p=0.19$ for the complete pattern. (b) With old disordered structure, leading to $\mathrm{Rp}=0.14$

\section{B. Structure description}

The view of the structure along the a-axis in fig. 4 visualises the two possible orientations of $\mathrm{SO}_{4}{ }^{2-}$. In the two configurations, the atomic arrangement can be described in term of two different layers parallel to (001): the first layer is composed of corner-linked $\mathrm{AlO}_{6}$ octahedra and $\mathrm{SO}_{4}$ tetrahedra, with $\left[\mathrm{Al}\left(\mathrm{SO}_{4}\right)_{2}\right]$ formulation, which alternates with a second layer built on ion $\mathrm{Na}^{+}$. Thus the individual layers are joined along the $\mathrm{c}$ axis by the interaction between monovalent atoms $\mathrm{Na}^{+}$and the $\mathrm{O} 1$ top oxygens of the tetrahedra in are layer that point down with those in the next layers which point up and so forth.

The corner-linkage between $\mathrm{AlO}_{6}$ octahedral and $\mathrm{SO}_{4}$ tetrahedral in both compounds is topologically identical to $\mathrm{ZrO}_{6}-\mathrm{PO}_{4}$ layer in some Zirconium phosphates $\mathrm{KZr}_{2}\left(\mathrm{PO}_{4}\right)_{3}[14], \mathrm{Zr}_{2}\left(\mathrm{NaPO}_{4}\right)_{4} \cdot 6 \mathrm{H}_{2} \mathrm{O}[15] \mathrm{ZrMH}\left(\mathrm{PO}_{4}\right)_{2}$, where $\mathrm{M}=\mathrm{K}$ or $\mathrm{Na}[16]$. The , $\alpha$ $\mathrm{Zr}\left(\mathrm{HPO}_{4}\right)_{2} \cdot \mathrm{H}_{2} \mathrm{O}[17]$, and $\mathrm{Na} \mathrm{Al} \mathrm{Zr}\left(\mathrm{PO}_{4}\right)_{2}(\mathrm{OH})_{2} \cdot \mathrm{H}_{2} \mathrm{O}[18]$.

In first $\mathrm{S}-\mathrm{O}_{4}$ Tetrahedral $\left(\mathrm{p}_{1}=0.70\right)$, the average $\mathrm{S}-\mathrm{O}_{4}$ distance is $(1.496 \AA$; values range from 1.467 to $1.584 \AA)$, the angle of the base oxygen, sulphur and the top oxygen is 110,6 and that of the base oxygen, sulphur and base oxygen is $105,1^{\circ}$. In the second $\mathrm{S}_{-} \mathrm{O}_{4}$ Tetrahedral $(30 \%)$, the average $\mathrm{S}-\mathrm{O}$ distance is $1.577 \AA$; ranges from 1.575 to $1.584 \AA$. The angle formed by $\mathrm{O}_{1}-\mathrm{S}-\mathrm{O}_{2}$ is 105,1 and that of the $\mathrm{O}_{2}-\mathrm{S}-\mathrm{O}_{2}$ is $113,4^{\circ}$ (table 3 ). In $\mathrm{KAl}\left(\mathrm{SO}_{4}\right)_{2}$, the S-O distance range from 1.431 to $1.442 \AA$, and the angle formed by the top oxygen sulfur and base oxygen is 110 and that of the base oxygen and sulfur is $108,94^{\circ}$ (Table 2).

The distance between aluminium and oxygen is $2.018(1) \AA$ in the first orientation and $\mathrm{Al}-\mathrm{O}$ bond length is $1.8(3)$ in the second. In the pure potassium KAI $\left(\mathrm{SO}_{4}\right)_{2}[15]$ the Al-O bond length is 1.909(1) (Table 3).

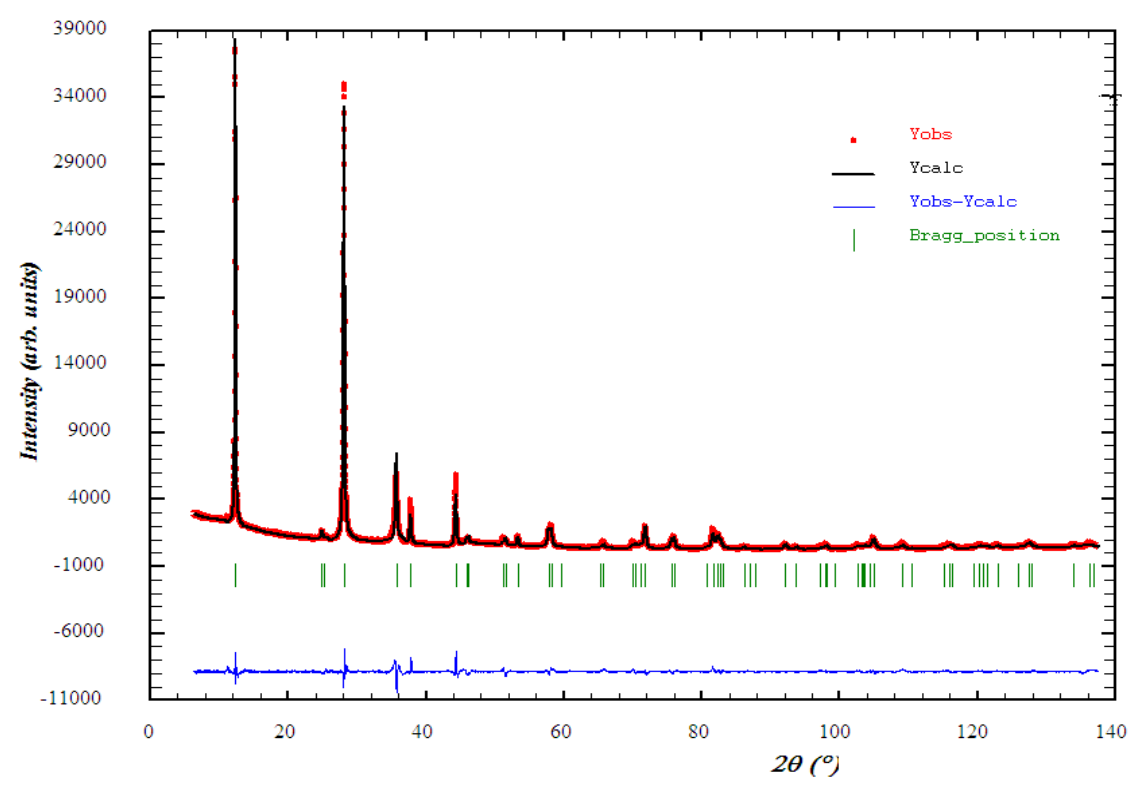

Figure. 3: Observed, calculated and difference curve of $\mathrm{NaAl}\left(\mathrm{SO}_{4}\right)_{2}$ 
Table 1: Conditions of X-ray data collection and crystallographic characteristics of $\mathrm{NaAl}\left(\mathrm{SO}_{4}\right)_{2}$

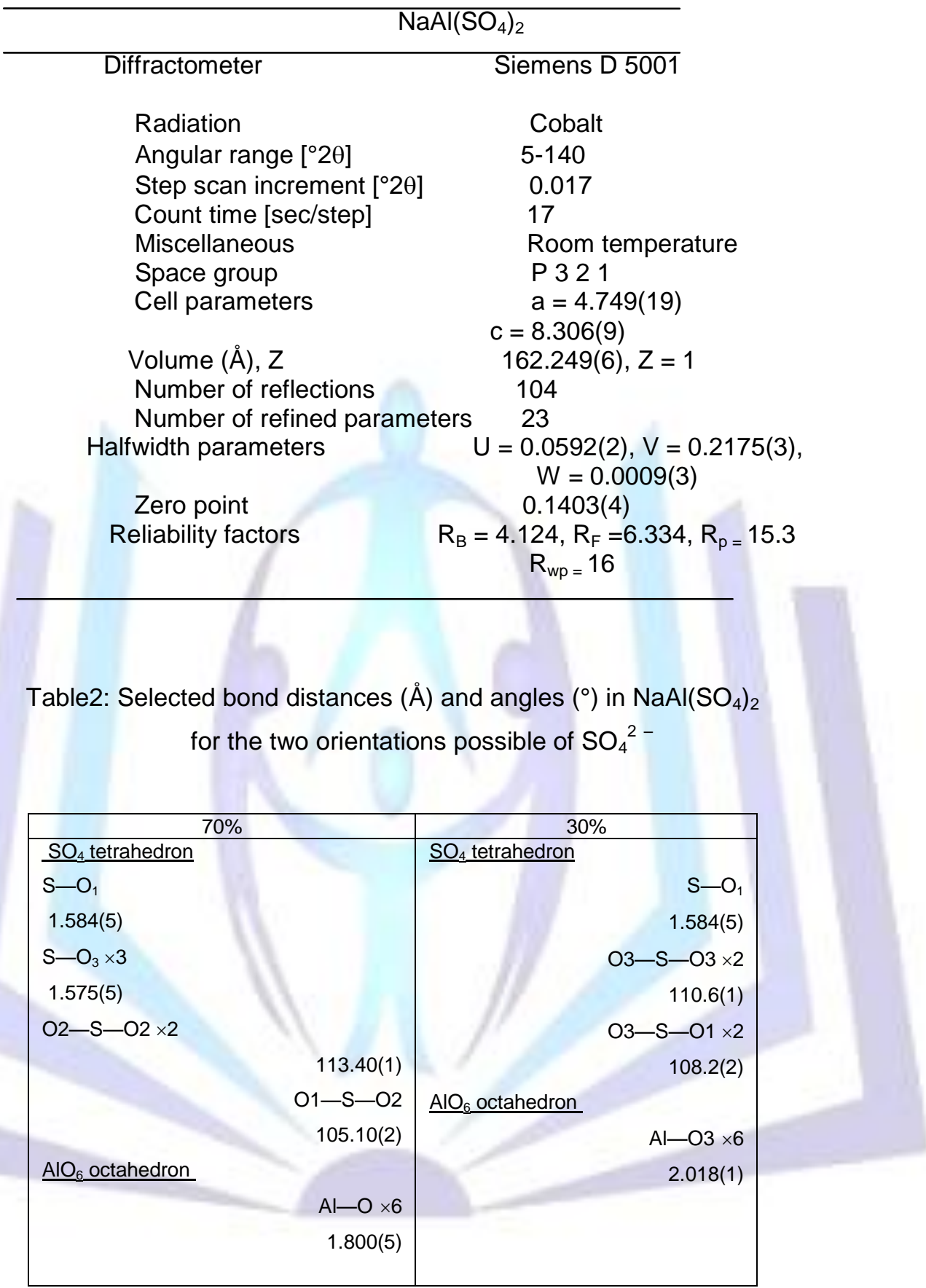


Table 3. The refined structural parameters for $\mathrm{NaAl}\left(\mathrm{SO}_{4}\right)_{2}$ and equivalent isotropic displacement parameters

\begin{tabular}{|l|c|c|c|c|}
\hline Atomes & $\mathrm{X}$ & $\mathrm{Y}$ & $\mathrm{Z}$ & Biso $\left(\AA^{2}\right)$ \\
\hline $\mathrm{Al}$ & 0 & 0 & 0.5 & $0.0695(16)$ \\
\hline $\mathrm{Na}$ & 0 & 0 & 0 & $0.395(8)$ \\
\hline $\mathrm{S}$ & $1 / 3$ & $2 / 3$ & $0.3098(4)$ & $0.0391(10)$ \\
\hline $\mathrm{O}_{1}$ & $1 / 3$ & $2 / 3$ & $0.1191(5)$ & $0.0241(10)$ \\
\hline $\mathrm{O}_{2}{ }^{*}$ & $0.253(11)$ & $0.939(14)$ & $0.3593(7)$ & $0.0241(10)$ \\
\hline $\mathrm{O}_{3}{ }^{*}$ & $0.628(3)$ & $0.959(4)$ & $0.3651(18)$ & $0.0241(10)$ \\
\hline
\end{tabular}

* rate of occupation $\left(\mathrm{O}_{2}=70 \% \cdot \mathrm{O}_{3}=30 \%\right.$ for the Rietveld refinement of $\mathrm{NaAl}\left(\mathrm{SO}_{4}\right)_{2}$

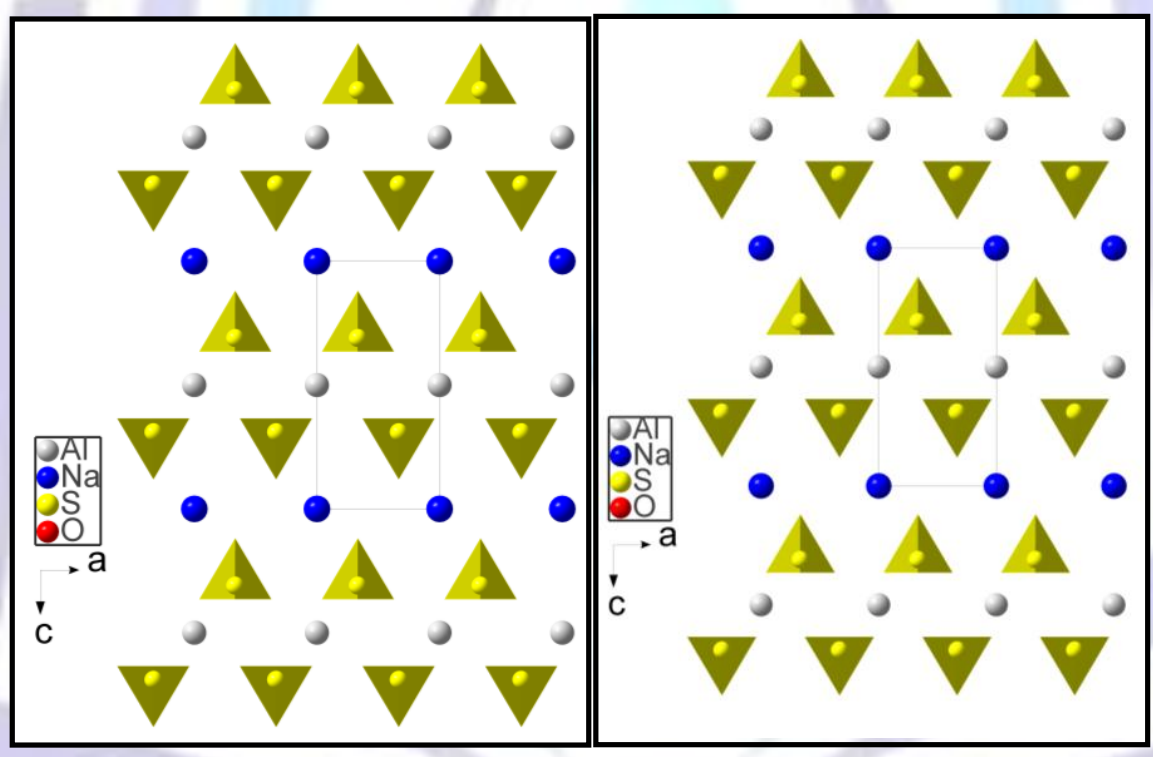

$P=30 \%$

Figure 4: Projection of the $\mathrm{NaAl}\left(\mathrm{SO}_{4}\right)_{2}$ disordered structure in the (011) plan, showing the two possible orientation of $\mathrm{SO}_{4}{ }^{2-}$ tetrahedral

\section{References}

[1] V. Ivanovski, V. Molecular structure 480-481, (1999) 689-693

[2] Fleck, M .and Kolitsch,U : Natural and synthetic compounds with krohnkite-type chains: an update . Z. Kristallogr; 218, (2003) 553-567.

[3] Giester. G, Monatshefte fuer Chemie and verwandte teile anderer Wissenschaften (1978)109.

[4] G. Giester Mineralogy and petroly 48(1993)227-233

[5] A Leclaire, MM Barel, J Chardon, B Raveau Journal of Solid State 116(1995) 364-368.

[6] Miao and Torardi, J.Solid state Chimistry; 155(2000) 229-232.

[7] Nikolaev V.P., Sadikov G. G., Lavrov A.V., Porai Koshits M. A, Inorg. Mater. 19 (1983) 876-880.

[8] C. Bernard J.PHYSICS AND Chemistry of solids28(1966)1427-1440. 
[9] S. Menchetti and C. Sabelli, N. J. Miner. Mh406(1976).

[10] H. M. RIETVELD, Acta. Crystallogr 22(1967),151.

[11] J. Rodrigaez-Carvajal, "Program FULLPROF", version 2.6. (2009).

[12] A. Le Bail, NIST SPECIAL Publication 846, (1992) 213.

[13] Fleck, M. kolitsch, U. Herweck, B. Z. Kristallogr; 217, (2002) 435-443.

[14] Brownfield, M.E., Foord, E. E, Sutley, S. J, Botinelly, T Am. Mineral, 78, (1993) 653-656.

[15] Manoly J M, Herpin P. pannetier G, Bulletin de la société chimique de France (1970) 98-101.

[16] Clearfield, A, Mc Cusker, L. B., Rudolf, P.R (1984).Inorg. Chem., 23,4679-4682.

[17] Poojary D.M and Clearfield, A. Inorg. Chem, 33, (1994) 3685-3688.

[18] Kolitsch,U. Eur. J.Mineral. 15, (2003)1029-1034. 